\title{
Development of the Biogas-Energized Livestock Feed Making Machine for Breeders
}

\author{
Herry Susanto ${ }^{1,2}$, Roy Hendroko Setyobudi ${ }^{2,4^{*}}$, Didik Sugiyanto ${ }^{1}$, Syukri Muhammad Nur ${ }^{2}$, \\ Erkata Yandri $^{2}$, Herianto Herianto ${ }^{3}$, Yahya $\mathrm{Jani}^{5}$, Satriyo Krido Wahono ${ }^{6}$, \\ Praptiningsih Gamawati Adinurani ${ }^{7}$, Yanuar Nurdiansyah ${ }^{8}$, and Abubakar Yaro $^{9}$ \\ ${ }^{1}$ Department of Mechanical Engineering, Darma Persada University, Jl. Taman Malaka Selatan \\ No.22, Jakarta Timur, 13450, Indonesia \\ ${ }^{2}$ Graduate School of Renewable Energy, Darma Persada University \\ ${ }^{3}$ Department of Information System, Darma Persada University \\ ${ }^{4}$ Department of Agriculture Science, Postgraduate Program, University of Muhammadiyah Malang, \\ Jl. Raya Tlogomas No.246, Malang, 65145, Indonesia \\ ${ }^{5}$ Department of Biology and Environmental Science, Linnaeus University, Stuvaregatan 4 \\ SE-392 31 Kalmar, Sweden \\ ${ }^{6}$ Research Division for Natural Product Technology - Indonesian Institute of Sciences, \\ Jl. Jogja - Wonosari, km 31.5, Gunung Kidul, Special Region Yogyakarta 55861, Indonesia \\ ${ }^{7}$ Department of Agrotechnology, Merdeka University of Madiun, Jl. Serayu No.79, \\ Madiun 63133, East Java, Indonesia \\ ${ }^{8}$ Program Study of Information Technology, University of Jember, Jl. Kalimantan 37, \\ Jember 68121, Indonesia \\ ${ }^{9}$ Institute of Health Sciences \& Research, AHRO Scientific Publishing, 272 Bath Street, \\ Glasgow G2 4JR, Scotland, UK
}

\begin{abstract}
The need for beef in Indonesia continues to increase. In 2020, it will require imports of 300 thousand $t$ of meat or the equivalent of $1.7 \times 10^{6}$ cattle a year. To overcome the problem, the biogas-energized livestock feed making machine (copper) was designed. The advantage of this copper is the process of making the livestock feed can efficient and effective. Results of the calculations, known that with increasing miller rotation output, the resulting capacity shows an increase. Also, it can use drive motors that are available on the market with a power capacity of $50 \mathrm{~W}$. Hence; this machine is very efficient in the use of electricity, high economic value, convenient and easy move to other places. Electricity for the engine is designed with renewable energy, namely biogas from co-digestion substrates namely animal feed waste, kitchen waste, cow dung and excreta disposal from septic tanks. This co-generation is expected to improve the life of the breeders
\end{abstract}

Key words: Copper, livestock feed, renewable energy, waste to energy, zero waste, economic value

\section{Introduction}

Indonesia is an archipelago country and very suitable to be used as a livestock business centre. Indonesia's land area reaches millions of $\mathrm{km}^{2}$, very supportive of livestock activities that require large areas. Indonesia's position in the trophic area is also very supportive of

\footnotetext{
* Corresponding author: roy_hendroko@ hotmail.com
} 
livestock business activities because this allows the territory of Indonesia to be exposed to the solar and the rain throughout the year. This makes the need for various livestock business activities such as water and forage easily obtained in Indonesia. This excellent natural condition is also supported by the very large population of Indonesia. Until the year 2020 , the population in Indonesia has reached $2.68 \times 10^{8}$ peoples. This number is certainly a very large number for a developing country. The very large population of Indonesia is certain to need food from livestock.

The need for some domestic livestock has not been fulfilled. Most of the shortages of livestock products are still being overcome by importing them to several neighbouring countries. Reference [1] stated, Indonesia in 2020, it will require imports of 300 thousand $t$ of meat or the equivalent of $1.7 \times 10^{6}$ cattle a year.

To overcome the problems faced by breeders in Indonesia, one solution is to develop the livestock feed making machine (copper). At this time, many equipment's or machines for making the livestock feed have been developed. Some of them have developed types of fish feed making machine [2-7], there are also those who develop types of chicken feed making machines [7-10], there are also those who develop types of cow feed making machines [11], there are also those who develop other types of livestock feed making machines [12-16], and some have even developed a kind of livestock feed drying machine using renewable energy $[18,19]$. Hence, the development of the machine types for making the livestock feed becomes a challenge and also a solution for breeder's communities in their efforts to improve their economy and prepare for facing increasingly fierce competition.

\section{Research methodology}

\subsection{Research flow diagram}

In this paper, the research steps are shown in the following research flow diagram in Figure 1:

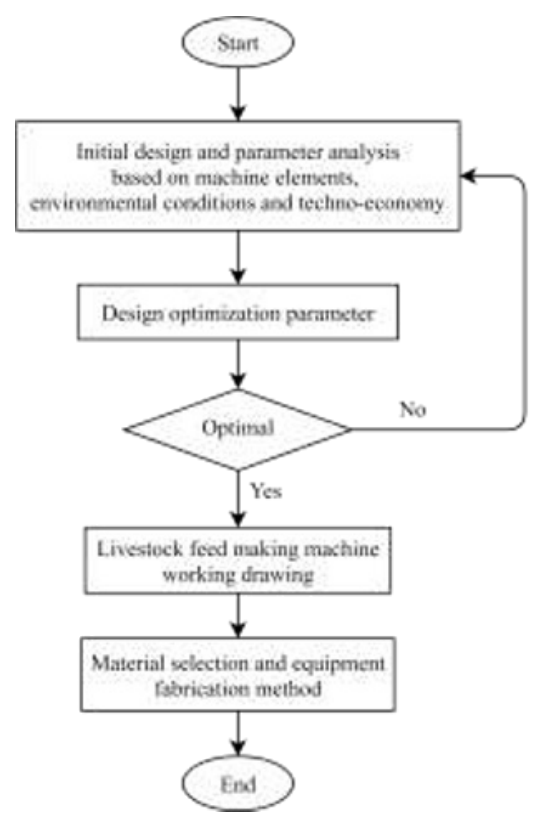

Fig. 1. Research flow diagram. 


\subsection{The biogas-energized livestock feed making machine}

Design of the livestock feed making machine to be studied can be seen in Figure 2, the advantage of this machine is the process of making the livestock feed can be done continuously as long as the raw ingredients for feed are still available. The raw ingredients that can be used to make the livestock feed using this machine are all kinds of ingredients for livestock feed in accordance with the conditions available in the place. The main components of the machine for making the livestock feed shown as in Figure 2:

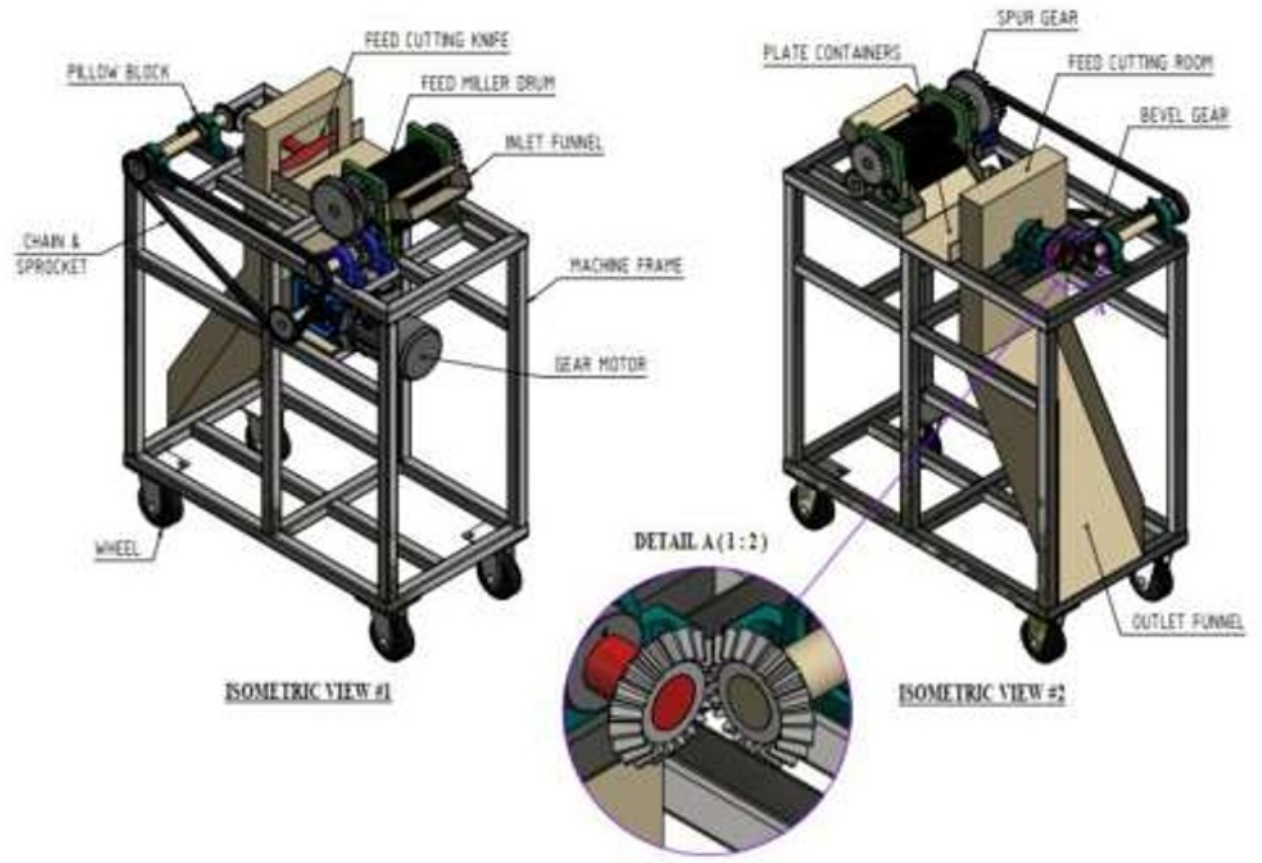

Fig. 2. The biogas-energized livestock feed making machine.

The main components of the livestock feed making machine consist of:

i). Inlet funnel.

ii). Feed miller drum.

iii). Spur gear.

iv). Feed cutting room.

v). Feed cutting knife.

vi). Bevel gear.

vii). Shaft.

viii). Pillow block.

ix). Chain \& sprocket.

$\mathrm{x})$. Gear motor.

xi). Plate containers.

xii). Machine frame.

xiii). Fixed \& swivel wheel.

xiv). Outlet funnel. 
This machine is designed to be portable for easy operation, does not take up much space, and easy to move. Overall, the dimensions of this machine are shown in Figure 3.

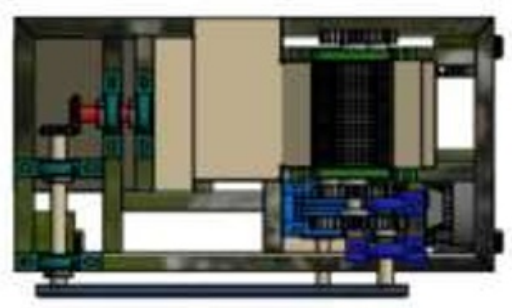

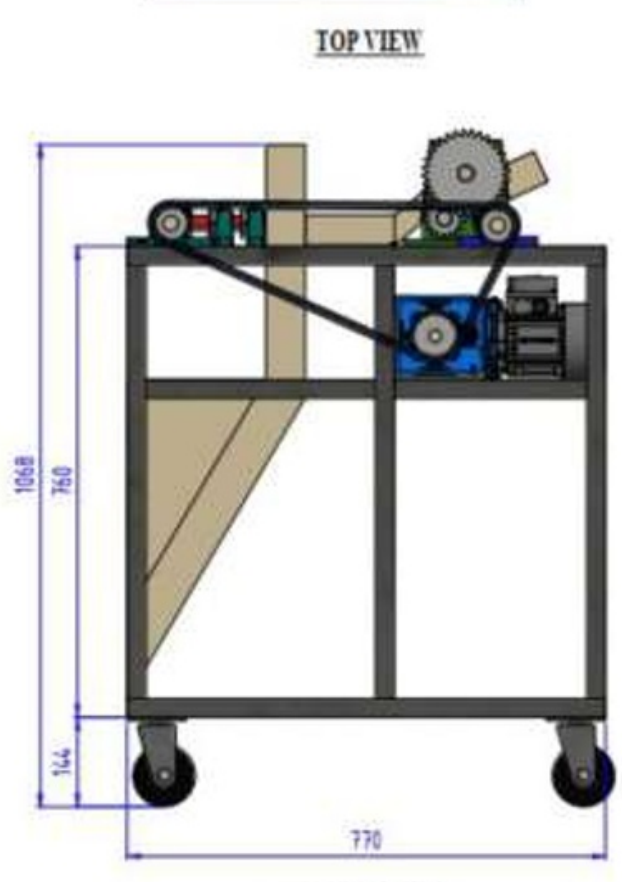

ERONT IIENI

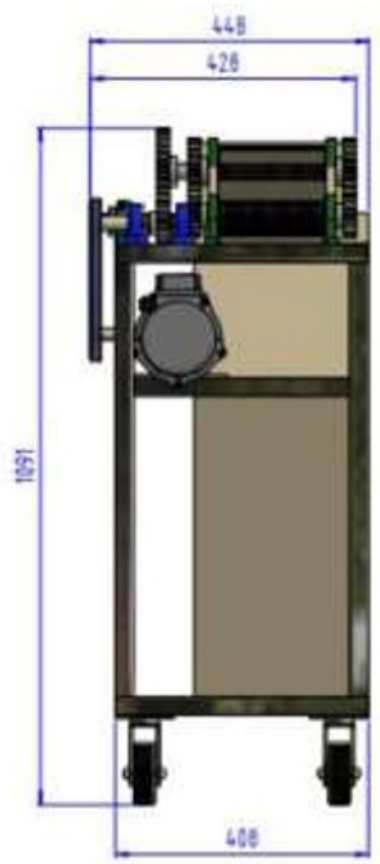

RIGHI IIEII

Fig. 3. Dimension of the biogas-energized livestock feed making machine.

\subsection{Working principle of the biogas-energized livestock feed making machine}

The livestock feed making machine are designed to be placed on the livestock area. This machine is used to milled and chop the raw ingredients for the livestock feed, where the process starts by entering the raw ingredients through the inlet funnel, then the raw ingredients is milled as it passes through the feed miller drum. Furthermore, the milled product will be distributed to the feed cutting room to be chopped. The results of the chopped will be channelled out through the outlet funnel. And the results of this chopping will later be used as the livestock feed. The working principle of this machine is as shown in Figure 4. 


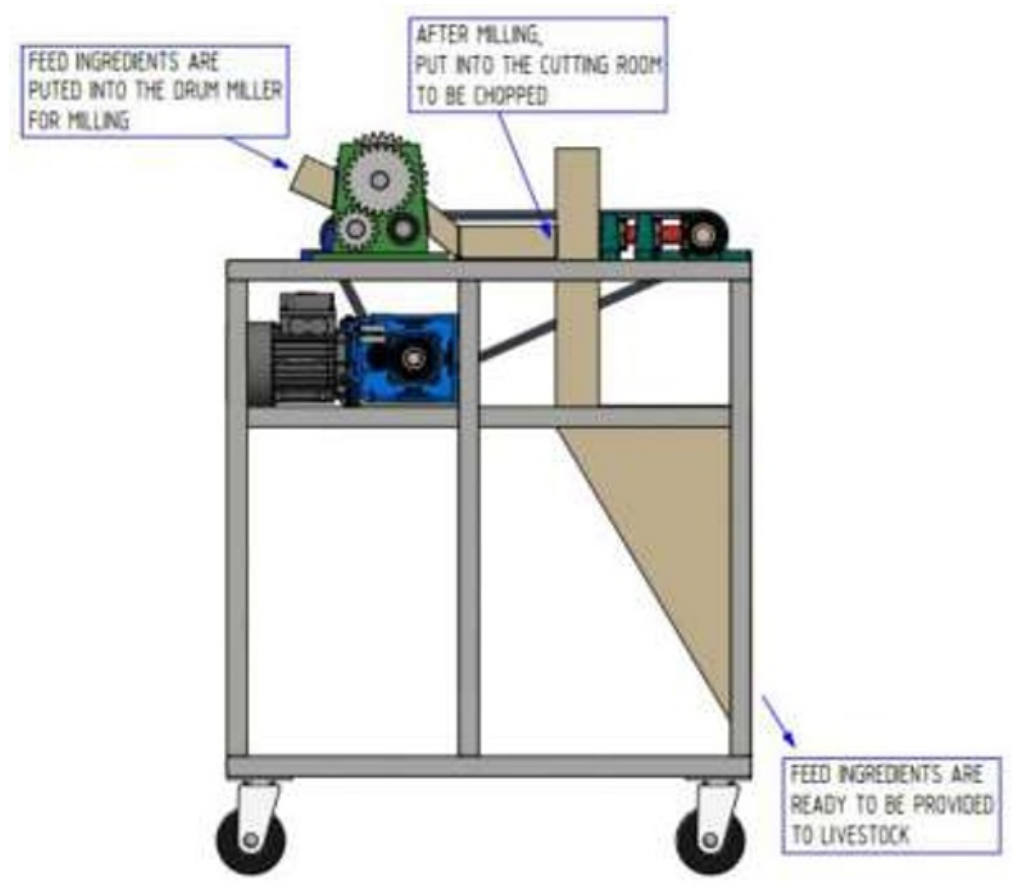

Fig. 4. Working principle of the biogas-energized feed making machine.

\subsection{Energy sources of the biogas-energized livestock feed making machine}

The biogas-energized livestock feed making machine is designed to save electric power. And the electric power used is electric power generated from biogas that comes from the livestock itself. Thus, the energy used is independent energy that does not come from the electricity grid of the State Electricity Company (PLN = Perusahaan Listrik Negara).

The biogas is the gas produced by microbes as a result the presence of fermentation of organic matter, in anaerobic state, both from the side temperature, humidity side, and side the acidity. The organic ingredients is then put into the digester (airtight enclosed space), hence the decomposition of organic ingredients will occur which results in the gas output (biogas) [19-21]. Biogas reactor house hold installation as shown in Figure 5.

The reactor in Figure 5 can be built in each farmer's house, or a combined reactor managed by several houses. Water is added to the inlet and mixed by co-digestion substrates [22-24], namely animal feed waste, kitchen waste, fallen leaves, grass, and cow dung. The biogas discharge pipe goes to the holder.

Next, it is distributed to a small generator to generate electricity to machine copper. The biogas isn't supplied only to the small generator. But also the stove in the kitchen for cooking and the biogas lamp for lighting houses and cowsheds, as a co-generation system.

The outlet, produced a slurry and digestate. The reactor liquid waste, in the form of a slurry, can be used as liquid organic fertilizer. Digestate as solid waste is used as a mixture of fish feed and solid organic fertilizer.

To maintain environmental health and increase biogas production, the biogas reactor can also be provided with inlet pipes from excreta disposal from septic tanks from each household. Figure 6 shows this biogas latrines system, as presented by [25]. 


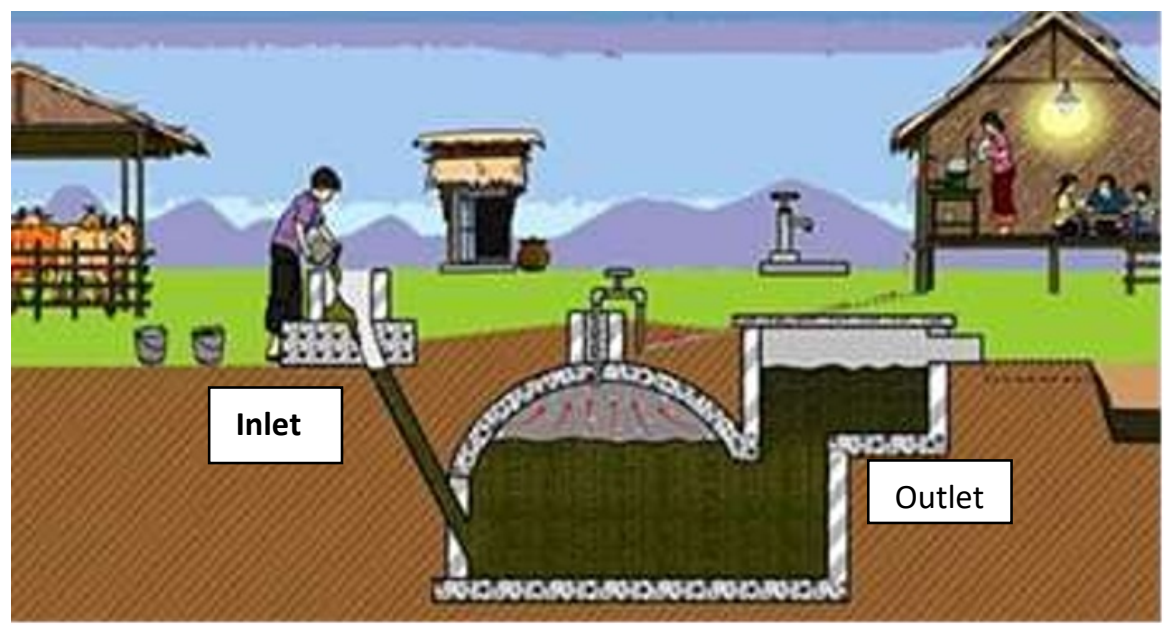

https://www.konfrontasi.com

Fig. 5. Utilization of biogas from livestock manure and co-digestion with other organic waste.

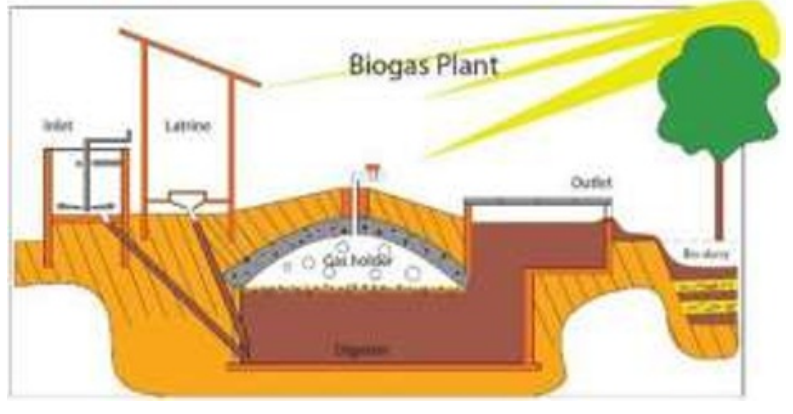

https://www.greenoptimistic.com/

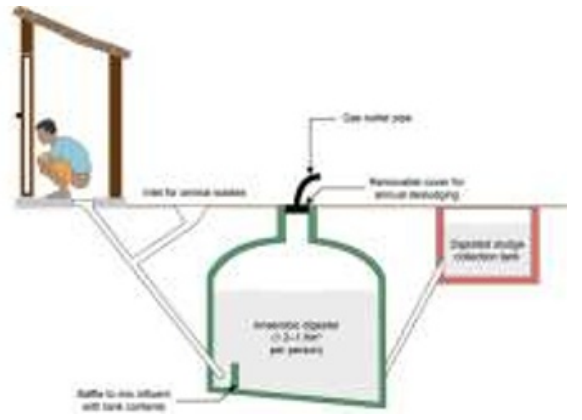

https://www.open.edu/

Fig. 6. Latrine biogas mixed co-digestion with other organic waste.

In addition, the electric power used to operate this copper comes from the biogas reactor developed in the livestock area. Hence, it can save costs for the production of the livestock feed, because there is no need to spend monthly electricity payments. On the contrary, if it is developed further it will be able to generate and supply electricity for other purposes, which in the end will be a source of additional income outside of the livestock business.

The copper is also useful for preparing pre-treatment for substrates, especially reducing the paricle size. Reference [26-28] state that small particles will have a large surface area with the impact of increasing biogas production. Reference [29-31] suggest a two-stage reactor system in managing multi feed, because it tends to be acidic due to low buffering capacity.

The application of a closed cyclus system in the form of a biorefinery in Figure 5 and Figure 6 has a zero waste impact which will improve health in the settlements of breeders, as described by $[25,32]$. 


\section{Equation}

The biogas-energized livestock feed making machine is designed to be used to produce good quality the livestock feed. To get optimal capabilities from this machine design, then some design parameters that are needed, such as the maximum capacity, and the required motor power. The performance of this machine, can be known through the following Equation. The motor rotation output can be calculated using the Equation (1) $[4,12,17,18]$ :

$$
n_{m}=\frac{f_{m}}{f_{t}} \cdot n_{o}
$$

The miller drum rotation on the sprocket can be calculated using the Equation (2):

$$
n_{m d 1}=\frac{z_{m}}{z_{m d 1}} \cdot n_{m}
$$

The miller drum rotation on the spur gear can be calculated using the Equation (3):

$$
n_{m d}=\frac{z_{s g 1}}{z_{s g}} \cdot n_{m d 1}
$$

The chopped knife rotation can be calculated using the Equation (4):

$$
n_{c k}=\frac{z_{m}}{z_{c k}} \cdot n_{m}
$$

The milling speed can be calculated using the Equation (5):

$$
v_{m d}=\frac{\pi \cdot D_{m d} \cdot n_{m d}}{60000}
$$

The chopped speed can be calculated using the Equation (6):

$$
v_{c k}=\frac{\pi \cdot D_{c k} \cdot n_{c k}}{60000}
$$

The maximum capacity can be calculated using the Equation (7):

$$
Q_{m}=\frac{3600}{1000} \cdot A \cdot v_{m d} \cdot \rho
$$

The mass of material moved per length can be calculated using the Equation (8):

$$
W_{m}=\frac{5 \cdot Q_{m}}{18 \cdot v_{m d}}
$$

The effective force of material moved can be calculated using the Equation (9):

$$
F_{e}=\frac{2 \cdot W_{m} \cdot\left(v_{m d}+v_{c k}\right)}{L}
$$

The required power can be calculated using the Equation (10):

$$
P=F_{e} \cdot\left(v_{m d}+v_{c k}\right)
$$

The required motor power can be calculated using the Equation (11): 


$$
P_{m}=\frac{P}{\eta_{m}}
$$

where : $\quad \mathrm{f}_{\mathrm{m}} \quad=$ Operational frequency of the inverter $(\mathrm{Hz})$

$\mathrm{f}_{\mathrm{t}} \quad=$ Maximum frequency of the inverter $(\mathrm{Hz})$

$\mathrm{n}_{\mathrm{o}} \quad=$ Maximum output rotation of the motor (rpm)

$\mathrm{n}_{\mathrm{m}} \quad=$ Operational output rotation of the motor (rpm)

$\mathrm{n}_{\mathrm{md}}=$ Output rotation of the miller drum on the spur gear (rpm)

$\mathrm{n}_{\mathrm{md} 1}=$ Output rotation of the miller drum on the sprocket (rpm)

$\mathrm{n}_{\mathrm{ck}}=$ Output rotation of the chopper knife (rpm)

$\mathrm{Z}_{\mathrm{m}} \quad=$ The number of the sprocket teeth on the motor (th)

$\mathrm{Z}_{\mathrm{md} 1}=$ The number of the sprocket teeth on the miller drum (th)

$\mathrm{z}_{\mathrm{ck}} \quad=$ The number of the sprocket teeth on the chopper knife (th)

$\mathrm{z}_{\mathrm{sg} 1}=$ The number of the spur gear pinion teeth on the miller drum (th)

$\mathrm{Z}_{\mathrm{sg}}=$ The number of the spur gear teeth on the miller drum (th)

$\mathrm{D}_{\mathrm{md}}=$ Diameter of the miller drum $(\mathrm{mm})$

$\mathrm{D}_{\mathrm{ck}}=$ Diameter of the chopper knife $(\mathrm{mm})$

$v_{\mathrm{md}}=$ Miller speed $\left(\mathrm{m} \mathrm{s}^{-1}\right)$

$v_{\mathrm{ck}}=$ Chopper speed $\left(\mathrm{m} \mathrm{s}^{-1}\right)$

$\mathrm{L} \quad=$ Milling length $(\mathrm{m})$

$\mathrm{Q}_{\mathrm{m}} \quad=$ Maximum capacity $\left(\mathrm{t} \mathrm{h}^{-1}\right)$

A = Material moved cross-sectional area $\left(\mathrm{m}^{2}\right)$

$\rho \quad=$ Density of material moved (s)

$\mathrm{W}_{\mathrm{m}}=$ Mass of material moved per length $\left(\mathrm{kg} \mathrm{m}^{-1}\right)$

$\mathrm{F}_{\mathrm{e}} \quad=$ Effective force of material moved $(\mathrm{N})$

$\mathrm{L} \quad=$ Distance moved $(\mathrm{m})$

$\mathrm{P} \quad=$ Required power $(\mathrm{W})$

$\mathrm{P}_{\mathrm{m}} \quad=$ Required motor power $(\mathrm{W})$

$\eta_{\mathrm{m}}=$ Motor efficiency $(0.85)$

\section{Result and discussion}

\subsection{Calculation and analysis of the biogas-energized livestock feed making machine performance}

The following are the initial design parameter to calculate the performance of the livestock feed making machine. These data are shown in Table 1.

Table 1. Initial design parameter of the livestock feed making machine.

\begin{tabular}{|c|l|c|c|}
\hline No & \multicolumn{1}{|c|}{ Parameters } & Value & Unit \\
\hline 1 & Material moved & Bulrushes & \\
\hline 2 & Equipment type & Feed Making Machine & \\
\hline 3 & Motor rotation $(\mathrm{n})$ & 1400 & $\mathrm{rpm}$ \\
\hline 4 & Gearbox ratio & $1: 20$ & \\
\hline 5 & Motor rotation output $\left(\mathrm{n}_{\mathrm{m}}\right)$ & 70 & $\mathrm{rpm}$ \\
\hline 6 & Miller drum diameter $\left(\mathrm{D}_{\mathrm{md}}\right)$ & 80 & $\mathrm{~mm}$ \\
\hline 7 & Chopper knife diameter $\left(\mathrm{D}_{\mathrm{ck}}\right)$ & 200 & $\mathrm{~mm}$ \\
\hline 8 & Distance Moved $(\mathrm{L})$ & 0.39 & $\mathrm{~m}$ \\
\hline
\end{tabular}

Table 1 continue to the next page 
Table 1 Continued

\begin{tabular}{|c|l|c|c|}
\hline No & \multicolumn{1}{|c|}{ Parameters } & Value & Unit \\
\hline 9 & Material moved cross-sectional area $(A)$ & 0.08 & $\mathrm{~m}^{2}$ \\
\hline 10 & Density of material moved $(\rho)$ & 157 & $\mathrm{~kg} \mathrm{~m}^{-3}$ \\
\hline 11 & Motor efficiency $\left(\eta_{\mathrm{m}}\right)$ & 0.85 & \\
\hline
\end{tabular}

Note: $1 \mathrm{rpm}=1 / 60 \mathrm{~Hz}(\mathrm{SI})$

The data in Table 1 will be used as a reference to calculate the livestock feed making machine performance using the Equation (1) to the Equation (11) as shown in Table 2.

Table 2. Calculation results of the livestock feed making machine performance.

\begin{tabular}{|c|c|c|c|c|c|c|c|c|}
\hline $\begin{array}{l}\text { Miller } \\
\left(\mathbf{r p m}^{*}\right)\end{array}$ & $\begin{array}{c}\text { Chopper } \\
(\mathbf{r p m})\end{array}$ & $\begin{array}{c}v_{\mathrm{md}} \\
\left(\mathrm{m} \mathrm{s}^{-1}\right)\end{array}$ & $\begin{array}{c}v_{\mathrm{ck}} \\
\left(\mathrm{m} \mathrm{s}^{-1}\right)\end{array}$ & $\begin{array}{c}\mathbf{Q}_{\mathbf{c}} \\
\left(\mathbf{t} \mathbf{h}^{-1}\right)\end{array}$ & $\begin{array}{c}W_{m} \\
\left(\mathrm{~kg} \mathrm{~m}^{-1}\right)\end{array}$ & $\begin{array}{l}F_{e} \\
(N)\end{array}$ & $\begin{array}{c}\mathbf{P} \\
(\mathbf{W})\end{array}$ & $\begin{array}{r}\mathbf{P}_{\mathbf{m}} \\
(\mathbf{W})\end{array}$ \\
\hline 35.3 & 70.7 & 0.148 & 0.740 & 0.72 & 1.34 & 6.1 & 5.4 & 6.4 \\
\hline 36.3 & 72.7 & 0.152 & 0.761 & 0.74 & 1.34 & 6.3 & 5.7 & 6.8 \\
\hline 37.3 & 74.7 & 0.156 & 0.782 & 0.76 & 1.34 & 6.5 & 6.1 & 7.1 \\
\hline 38.3 & 76.7 & 0.161 & 0.803 & 0.78 & 1.34 & 6.6 & 6.4 & 7.5 \\
\hline 39.3 & 78.7 & 0.165 & 0.824 & 0.80 & 1.34 & 6.8 & 6.7 & 7.9 \\
\hline 40.3 & 80.7 & 0.169 & 0.845 & 0.82 & 1.34 & 7.0 & 7.1 & 8.3 \\
\hline 41.3 & 82.7 & 0.173 & 0.866 & 0.84 & 1.34 & 7.2 & 7.4 & 8.7 \\
\hline 42.3 & 84.7 & 0.177 & 0.887 & 0.86 & 1.34 & 7.3 & 7.8 & 9.2 \\
\hline 43.3 & 86.7 & 0.182 & 0.908 & 0.88 & 1.34 & 7.5 & 8.2 & 9.6 \\
\hline 44.3 & 88.7 & 0.186 & 0.929 & 0.90 & 1.34 & 7.7 & 8.5 & 10.1 \\
\hline
\end{tabular}

*Note: $1 \mathrm{rpm}=1 / 60 \mathrm{~Hz}(\mathrm{SI})$

The graphs in Figure 6 and Figure 7 are graphs of calculation results of the capacity, and the required motor power:

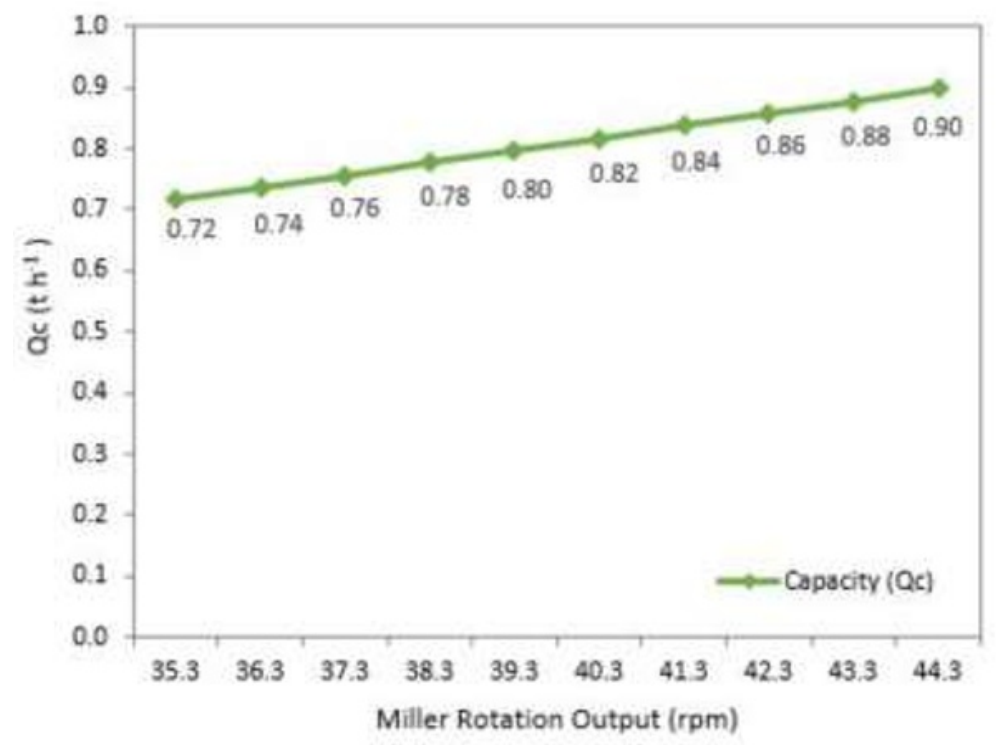


Fig. 7. Graph of the capacity vs the miller rotation output.

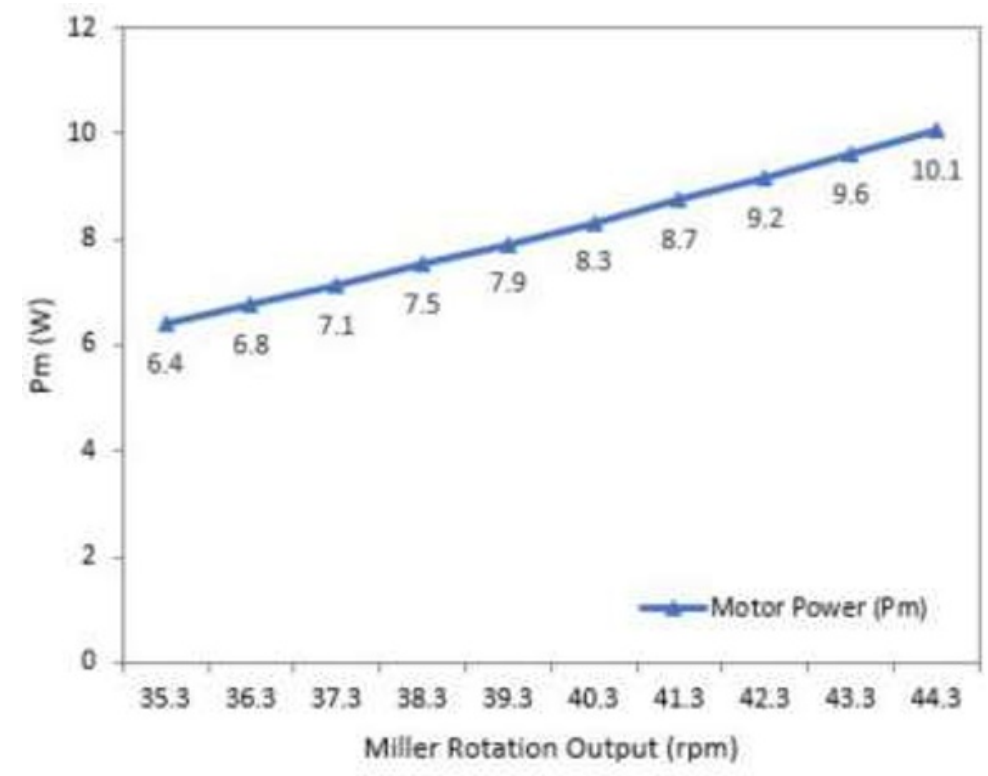

Fig. 8. Graph of the required motor power vs the miller rotation output.

\subsection{Discussion of the biogas-energized feed making machine}

In the development of the biogas-energized feed making machine, there are several things that must be considered properly, that is: This equipment will be washed frequently and will allow corrosion to occur, then all components, especially in the frame, must be coated with an anti-corrosion coating through the galvanic or hotdipe process [16, 17]. Then this equipment might be used also in areas that are still not reached by electricity, hence it needs to think about and develop the electrical energy source. The solution is by providing generators or power plants that use other renewable energy sources $[16,17]$. Then keep in mind the cleaning process and make a time schedule [13-18]. In addition, it is necessary to pay attention to the maintenance time of this equipment, hence it is more durable and is used longer [13-18]. Moreover, because the required motor power at maximum conditions is $10.1 \mathrm{~W}$, hence it can use motors that are available on the market with a power capacity of $50 \mathrm{~W}$.

\section{Conclusion}

From the results of the calculations, by varying the miller rotation output from a minimum rotation of $35.3 \mathrm{rpm}$ to a maximum rotation of $44.3 \mathrm{rpm}$. The capacity increase by $20.3 \%$. Moreover, the required motor power at maximum conditions is $10.1 \mathrm{~W}$. Hence, this machine is very efficient in the use of electricity and has high economic value. In addition, because it is designed to be portable, it makes the machine very practical and easy to move to other places. To improve welfare and health in the settlements of breeders, it is advisable to implement a closed cycle - biorefinery with biogas co-digestion as co-generation. 


\section{References}

1. R. Alika, RI Butuh 1,7 Juta Ekor Sapi Impor Setahun, Mentan: Tak Bisa Dibiarkan. [RI Needs 1.7 Million Cows Imported a Year, Minister of Agriculture: Cannot be ignored]. [Internet] from https://katadata.co.id/marthathertina/berita/5e9a498e6615b/ri-butuh-17-juta-ekor-sapiimpor-setahun-mentan-tak-bisa-dibiarkan (2020). [Accessed on 15 August 2020]. [in Bahasa Indonesia].

2. A. Nurhidayat, S.Y.R.S. Raha, PRIMA: Journal of Community Empowering and Services, 2,1:6-9(2018). [in Bahasa Indonesia]. https://jurnal.uns.ac.id/prima/article/view/35163/23293

3. M. Aris, F. Muhdar, e-Journal Budidaya Perairan, 8,2:22-28(2020) [in Bahasa Indonesia] https://ejournal.unsrat.ac.id/index.php/bdp/article/view/28901/28197

4. A.F. Dewinta, W.F. Ma'ruf, Scientific Journal of Fisheries and Marine, 12,1:8196(2020). https://e-journal.unair.ac.id/JIPK/article/view/14536/9933

5. W. Pangestika, S. Putra, Scientific Journal of Fisheries and Marine, 12,1:21-30(2020). https://e-journal.unair.ac.id/JIPK/article/view/18110/9936

6. M.A. Azahari, M. Hasan, S. Hajisame, N.A.N. Ali, M.F.H.A. Aziz, Scientific Journal of Fisheries and Marine, 12,1:1-9(2020).

https://e-journal.unair.ac.id/JIPK/article/view/18094/9908

7. A. Gafur, E.S. Wahyuni, JUARA: Jurnal Wahana Abdimas Sejahtera, 1,1:100 108(2020). [in Bahasa Indonesia]. https://trijurnal.lemlit.trisakti.ac.id/juara/article/view/6308/4835

8. J.R.F.S. Permana, Harianto, P. Susanto, JCONES, 3,2:51-58(2014). [in Bahasa Indonesia]. https://jurnal.dinamika.ac.id/index.php/jcone/article/view/322/271

9. N. Pratiwi, Warta Pengabdian, 12,2:263-270(2018). [in Bahasa Indonesia]. https://jurnal.unej.ac.id/index.php/WRTP/article/view/7311/6050

10. Y. Ahdiat F., Y. Prasetyo, A.C. Arifin, A. Aminudin, J-ADIMAS (Jurnal Pengabdian kepada Masyarakat), 7,2:86-90 (2019). [in Bahasa Indonesia]. https://jurnal.stkippgritulungagung.ac.id/index.php/jadimas/article/view/1452/646

11. A. Sarazi, Jamaluddin, R. Syahputra, Jurnal TEKTRO, 2,2:12-17(2018). [in Bahasa Indonesia]. http://e-jurnal.pnl.ac.id/index.php/TEKTRO/article/view/1627/1403

12. S. Nugroho, I. Setyowidodo, H. Istiqlaliyah, Jurnal Mesin Nusantara, 1,2:104113(2018). [in Bahasa Indonesia]. https://ojs.unpkediri.ac.id/index.php/JMN/article/view/13626/1269

13. A. Nugroho, A. Wibowonoto, TEKNIK: Jurnal Ilmiah Bidang Ilmu Kerekayasaan, 38,1:49-57(2017). [in Bahasa Indonesia]. https://ejournal.undip.ac.id/index.php/teknik/article/view/13803/11668

14. N.I.F. Nisa, A. Aminudin, Y.A. Fahrudi, JAST: Jurnal Aplikasi Sains dan Teknologi, 3,1:43-49(2019). [in Bahasa Indonesia]. https://jurnal.unitri.ac.id/index.php/jast/article/view/1284/pdf

15. A. Hanafie, Fadhli, I. Syahruddin, ILTEK: Jurnal Teknologi, 11,1:1484-1487(2016). [in Bahasa Indonesia]. http://journal-uim-makassar.ac.id/index.php/ILTEK/article/view/403/360

16. A. Efendi, R. Suhartono, SINTEK JURNAL: Jurnal Ilmiah Teknik Mesin, 13,1:4450(2019). [in Bahasa Indonesia]. https://jurnal.umj.ac.id/index.php/sintek/article/view/3605/3755 
17. H. Susanto, R.H. Setyobudi, Y. Chan, S.M. Nur, E. Yandri, J. Burlakovs, et al., IOP Conf. Series: Earth and Environmental Science, 490(012009):1-10(2020). https://iopscience.iop.org/article/10.1088/1755-1315/490/1/012009/pdf

18. H. Susanto, K. Abdullah, A.S. Uyun, S.M. Nur, T.M.I. Mahlia, MATEC Web of Conferences 164(01012):1-17(2018).

https://www.matecconferences.org/articles/matecconf/abs/2018/23/matecconf_icesti2018_01012/matecc onf icesti2018_01012.html

19. M.C. Santoso, I.A.D. Giriantari, W.G. Ariastina, Jurnal SPEKTRUM, 6,4:5865(2019). [in Bahasa Indonesia].

https://ojs.unud.ac.id/index.php/spektrum/article/view/55329/32748

20. T. Bond, M.R. Templeton. Energy Sustain. Dev. 2011, 15:347-354. https://doi.org/10.1016/j.esd.2011.09.003

21. K. Rajendran, S. Aslanzadeh, M. J Taherzadeh, A Review. Energies 2012, 5,8:29112942; https://doi.org/10.3390/en5082911

22. R.T. Romano, R.H. Zhang, Bioresour. Technol., 99:631-637(2008).

23. A.J. Ward, P.J. Hobbs, P.J. Holliman, D.L. Jones, Bioresour. Technol., 99:79287940(2008). https://doi.org/10.1016/j.biortech.2008.02.044

24. R. Hendroko, A. Wahyudi, S.K. Wahono, P.G. Adinurani, Salafudin, D. Salundik, et al. International Journal of Technology 4,3:202-208(2013). https://doi.org/10.14716/ijtech.v4i3.115

25. R. Hendroko, T. Liwang, Salafudin, L.O. Nelwan, G.A. Praptiningsih, S.K. Wahono, Biorefinery skala rumah tangga:Integrasi energi terbarukan - biogas dan pangan [Household scale biorefinery: integration of renewable energy - biogas and food]. Seminar Hasil Penelitian Semester Ganjil 2011/2012, Lembaga Penelitian, Pemberdayaan Masyarakat dan Kemitraan Universitas Darma Persada, (Jakarta, Indonesia, 2012), pp. 1-13. [in Bahasa Indonesia]

http://lp2mk.unsada.ac.id/wp-content/uploads/2016/04/PROSIDING-GJL-11-12.pdf

26. K.V. Kumar, V. Sridevi, K. Rani, M. Sakunthala, C.S. Kumar. Elixir Chem. Engg. 57 (2013) 14073-14079

https://www.elixirpublishers.com/articles/1364981651_57\%20(2013)\%201407314079.pdf

27. N. Khorshidi, B. Arikan, Experimental Practice in order to Increasing Efficiency of Biogas Production by Treating Digestate Sludge. [Thesis] (Sweden, University College of Borås, 2008). https://www.diva-portal.org/smash/get/diva2:1310640/FULLTEXT01.pdf

28. T.R. Sreekrishnan, S. Kohli, V. Rana, 2004. Bioresour. Technol. 95:1-10 https://doi.org/10.1016/j.biortech.2004.02.010

29. P.G. Adinurani, R.H. Setyobudi, S.K. Wahono, M. Mel, A. Nindita, E. Purbajanti, et al., Proc. Pakistan Acad. Sc 54,1:47-57(2017).

http://www.paspk.org/wp-content/uploads/2017/03/Proceedings-B.-Life-Sciences541-March-2017.pdf

30. P.G. Adinurani, A. Nindita, S.K. Wahono, M. Maizirwan, A. Sasmito, Y.A. Nugroho, et al., Energy Procedia, 65:264-273(2015).

https://doi.org/10.1016/j.egypro.2015.01.046

31. R.H. Setyobudi, A.Sasmito, P.G. Adinurani, A. Nindita, A.S. Yudhanto, Y.A. Nugroho, et al. Energy Procedia 65,2015:300-308(2015).

https://doi.org/10.1016/j.egypro.2015.01.056

32. R. Hendroko, T. Liwang, Salafudin, G.A. Praptiningsih, L.O. Nelwan, Y. Sakri, et al., Sinergi bio-metana berbahan baku limbah Jatropha curcas L., dan pangan dalam penerapan program kawasan rumah pangan lestari [Synergy of bio-methane made 
from Jatropha curcas L. waste, and food in the implementation of sustainable food home area program]. Prosiding Simposium dan Seminar Bersama PERAGIPERHORTI-PERIPI-HIGI, (Bogor, Indonesia, 2012), pp. 437-443. [in Bahasa Indonesia]

http://lipi.go.id/publikasi/sinergi-bio-metana-berbahan-baku-limbah-jatropha-curcas-ldan-pangan-dalam-penerapan-program-kawasan-rumah-pangan-lestari/20594 